\title{
Influence of Product Quality on Organizational Performance of Seed Maize Companies in Kenya
}

\author{
Munyaradzi Jonga ${ }^{1}$, Esther Waiganjo ${ }^{2} \&$ Agnes Njeru $^{2}$ \\ ${ }^{1}$ African Agricultural Technology Foundation, Nairobi, Kenya \\ ${ }^{2}$ School of Entrepreneurship, Procurement and Management, Jomo Kenyatta University of Agriculture and \\ Technology, Nairobi, Kenya \\ Correspondence: Munyaradzi Jonga, African Agricultural Technology Foundation, P.O. Box 30709-00100, \\ Nairobi, Kenya. Tel: 254-735-992-202. E-mail: jongamun@gmail.com
}

Received: December16, 2017

Accepted: February 25, $2018 \quad$ Online Published: April 15, 2018

doi:10.5539/jas.v10n5p109

URL: https://doi.org/10.5539/jas.v10n5p109

\begin{abstract}
A number of new seed entrepreneurs were established in Kenya, however, the majority of them fail to achieve the required business growth and competiveness. As a result, they remain small and producing less quantities of seed compared to the few large seed companies in the same market. This study evaluated the influence of product quality on organizational performance of seed maize companies in Kenya. The study adopted a cross-sectional survey research design to collect data from the target population which comprised of seed maize companies in Kenya. The sampling frame of the study was the registered seed maize companies at the Seed Trade Association of Kenya which was the unit of analysis while the respondents were the managerial employees within the seed companies and key seed experts in Kenya. Primary data was obtained by administering questionnaires to four employees within each seed company. The four employees were randomly selected from the production, marketing, finance and warehousing departments. The key seed experts were selected through snow balling and judgment technique. Interviews were conducted with the selected seed experts. The collected data was analyzed using SPSS software. Factor analysis was done to establish the appropriateness of the questionnaire constructs. Both descriptive and inferential statistics were used. Inferential statistics included the use of bivariate analysis and the study used the Pearson correlation coefficient. The study also ran a multiple regression model in order to establish the effect of product quality on organizational performance of seed maize companies. Results indicated that the original source of seed can affect product credibility and sales, seed certification standards influenced product credibility and sales, characteristics of seed varieties affect product performance and use of hotlines to report seed failure influences the credibility of the seed and the distributor. The study concludes that managers can increase profitability by putting in place appropriate quality management systems (QMS) and product quality standardization of seeds produced to ensure high quality seed. The study recommends that the management of seed companies should ensure they embark on improving the product quality of seeds produced so as to meet customer requirements and enhance the firm's performance. This can be achieved by implementing appropriate QMS, securing contracts with large farmers who have irrigation facilities to guarantee adequate seed fields isolation, high productivity and quality seed production.
\end{abstract}

Keywords: organizational performance, product quality, quality management systems, seed maize companies

\section{Introduction}

A bigger proportion of the countries in Africa rely on maize based cropping systems for food security and the main staple crop is maize. Seed can play a critical role in increasing agricultural productivity. According to Langyintuo et al. (2010) seed can be described as an essential, strategic, and relatively inexpensive input that often determines the upper limit of crop yields and the productivity of all other agricultural inputs. This is because if the farmers are provided with high optimized seed for the climates of various regions in Kenya, they can produce up to two times more grain per hectare than ordinary seed thus ensuring higher food security. However, one of the main challenges to maize productivity is the inadequate supply of high quality seed to farmers in Africa. It is with this concern that this study wishes to address the factors that facilitate development of a seed system that is robust and capable of generating, producing and distributing adequate and high quality 
new seed varieties that meet the needs of all farmers, in a cost-effective way and increase agricultural production.

Informal or on-farm seed systems vary among countries, regions and crops. They rely on seed saving practices, that is, keeping parts of the harvest for planting in the next season. The system usually plants local varieties of seed kept from the previous year's harvest, obtained from neighbours and/or the local market. This is the predominant system for food crops in subsistence agriculture. It is estimated that in developing countries, the informal seed systems are responsible for more than $80 \%$ of the total area planted with subsistence crops. They will likely continue to be the main source of seed for subsistence crops in the world. However, this system is not market oriented; seeds are usually produced for consumption. Some surplus can be barter traded with neighbours or sold to local grain dealers (FAO, 2004).

The informal seed sector has been in operation in Kenya particularly for the small scale farmers. According to the National Seed Policy document for Kenya, the source and quality of most of the planting materials and seed purchased, multiplied and marketed by the informal seed sector may not be known, yet this is the major source of planting material for the farmers. The informal sources of seed in Kenya include farm-saved seed, farmer-to-farmer exchange, local markets, Non-Governmental Organizations (NGOs) and Community Based Organizations (CBOs). Growers of flowers and ornamental plants do import and/or locally multiply planting material for their own use or sale to other local growers, yet they are not registered as seed dealers. Moreover, some Relief Agencies who supply emergency seed, do not always obtain such planting material from registered seed dealers, and so such seed may not be of known quality. However, the informal seed sector sometimes voluntarily use Kenya Plant Health Inspectorate Service (KEPHIS) seed testing services to determine the quality status of their seed for own use. As farming becomes more commercial, the focus is shifting towards the formal seed system though.

Formal seed traded and used in Kenya is made up of local production and imported seed. As part of the trade business, there are exports of seed to particularly its neighbours in the region. The movement of seed within and between countries can be restricted by regulations governing seed certification and standards, phytosanitary measures, variety testing and release procedures, plant variety protection, import and export requirements.

\subsection{Statement of the Problem}

The current demand for improved maize seed in Kenya is about 39000 tonnes, yet the seed companies operating in this market space can supply only $72 \%$ of this demand (Langyintuo et al., 2008). The shortfall in improved seed supply is being filled by use of inferior land races and other planting materials exchanged by smallholder farmers in their specific farming communities. The use of such unimproved planting materials, results in lower productivity and hence perennial food insecurity among the farming households (Pixley \& Banziger, 2004).

In order to address the maize seed supply challenges, a lot of studies on seed supply in Kenya and the whole East African region were undertaken. These studies identified policy issues, technical and funding challenges as the main factors impacting on the seed businesses (Langyintuo et al., 2008). Policy issues on variety release, access to superior germplasm, seed certification regulations, human skills in seed production, funding, etc. were cited as some of the major challenges faced by the seed industry especially the new seed entrepreneurs (AGRA, 2013). These challenges were tackled by various organizations in Kenya and elsewhere in Sub-Saharan Africa through the supply of superior germplasm by projects such as Drought Tolerant Maize for Africa (DTMA), Water Efficient Maize for Africa (WEMA), Alliance for a Green Revolution in Africa-Program for Africa's Seed System (AGRA-PASS), Improved Maize for African Soils (IMAS) and Insect Resistant Maize for Africa (IRMA). Kenya also has a robust variety registration process that resulted in 82 maize varieties released for commercialization between 2002-2006 (Setimela, Badu-Apraku, \& Mwangi, 2010) and the number grew to 240 varieties in 2014. This shows that the number of improved maize varieties available is no longer a limiting factor for the growth of seed companies. Furthermore, a lot of capacity building was done through seed business grants and loans, training of plant breeders and seed technologists in order to support growth of new seed entrepreneurs (AGRA, 2013).

Despite all these efforts to address the policy, regulatory, technical and funding challenges faced by new seed maize entrepreneurs, the seed demand of 39000 tonnes in Kenya is still being unmet. The supply of 28000 tonnes (which is $72 \%$ of the actual seed maize demand) is dominated by only five big seed companies yet there are 104 registered seed companies in Kenya (AGRA, 2013). These five big seed companies have been dominating the Kenya seed market for more than two decades. This is despite all the interventions done by various organizations, NGOs and projects to enhance the performance of the new seed maize entrepreneurs. 
The past and current interventions focus much on external and technical factors affecting seed businesses. However, these alone, are failing to catapult new seed entrepreneurs to strategic growth and performance levels that result in sustained business competitiveness in the Kenyan seed market that is dominated by just five major players who are not even meeting the full demand for improved maize seed. As highlighted by Langyintuo et al. (2009), the reforms done in the seed sector which resulted in four-fold increase in the number of seed companies in the last decade were insufficient as the quantity of seed marketed did not grow in tandem with the increase in number of seed companies. Furthermore, the Kenyan seed sector is classified to be in the Late Growth stage (stage 4) of seed sector development that is characterized among other things, by favourable seed policies that facilitated establishment of many new seed entrepreneurs, with 82 seed companies having been registered by mid-2010 (AFSTA, 2010) and growing to a total of 104 by 2012 (AGRA, 2013).

The major challenge is that the majority of the new seed entrepreneurs are not achieving the required growth to compete and contribute to the already unsatisfied seed maize market. Many new seed entrepreneurs remain small, producing less than 500 tonnes of seed annually (MacRobert, 2009). This study therefore, sought to establish the influence of product quality on organizational performance of seed maize companies in Kenya.

\subsection{Literature Review}

Terziovski, Samson, and Dow (1997) conducted a study whose objective was to test the relationship between ISO 9000 certification and organizational performance in the presence and absence of a total quality management (TQM) environment. The analysis was performed on a sample of 962 industrial companies in Australia and 379 from New Zealand and found that the ISO 9000 certification does not have a significantly positive organizational performance on its own. The authors say that the main motivation for companies to have a quality certification is the ability of certification to open doors to new customers that would be difficult to achieve without the quality certification. In this sense, Youngdahl and Kellogg (1997), examined the relationship between customer service, quality assurance, satisfaction and effort, all this in the perspective of the costs of quality and found that the classification of costs to quality customer service and their relationship with both satisfaction and effort, provides important capabilities to the design and implementation of services. Thus, the cost of quality concept predicts that as quality increases the total cost of quality decreases (Hendricks \& Singhal, 2001). The internal and managerial motivation to adopt ISO 9000 often has a positive effect on the likelihood of a certified organization to achieve a better-performing effectiveness configuration (Boiral \& Amara, 2009).

Casadesús and Giménez (2000) carried out an empirical study in 288 companies in the Autonomous Community of Catalonia, certified by ISO 9000, determining the internal and external benefits obtained after certification. They conclude that $65 \%$ of the companies acquired internal and external benefits, while $15 \%$ had more modest benefits. For the authors, there is no doubt that the process of certification according to ISO 9000, provides an evolution in how to manage a company, the organization, communication and quality system, in general are the key to success in business management. It takes a cultural change, which affects the whole organization, where continuous improvement has become a basic tool to advance business competitiveness.

Arawati, Ahmad, and Muhammad (2009) conducted a study on the impact of quality management (QM) practices on productivity and profitability using a sample of manufacturing companies in Malaysia. The results of the study revealed that quality measurement, benchmarking in particular, as well as employee focus, supplier relations and training appear to be of primary importance and exhibit significant impact toward productivity and profitability. In addition, the findings also suggest that productivity mediates the link between QM and profitability. The main objective of this study was to establish the influence of product quality on organizational performance of seed maize companies in Kenya.

\section{Methodology}

This study used a cross-sectional survey research design. A survey research design was an attempt to collect data from the members of a population in order to determine the current status of that population with respect to one or more variables. It was therefore, a self-report study which required the collection of quantifiable information from the sample. A survey research can be descriptive, exploratory or involving advanced statistical analyses (O. M. Mugenda \& A. G. Mugenda, 2003). The correlation approach was used and it involved collecting data in order to determine whether and to what degree a relationship exists between two or more quantifiable variables. The degree of relationship was expressed as a correlation coefficient (r). Since this study was concerned with discovery and deeper understanding of associations among different variables that affect seed business growth and financial performance, a descriptive study with correlational approach was used (Cooper \& Schindler, 2011).

The target population of this study comprised of 24 units of analysis which are the seed maize companies that are registered with the seed trade association of Kenya (STAK) from which the accessible population was drawn. 
The sample size for this study was 96 employees who were obtained first by selecting through purposive sampling four departments from each seed company, namely; production department, marketing department, finance department and warehousing department. Four employees from each seed company were randomly selected one each from the four departments. The study also interviewed 30 seed experts who were selected through snowballing technique who helped on elaboration of study variables. The snowball technique was used in conjunction with the judgment technique. This involved getting the sample through referral networks (Cooper $\&$ Schindler, 2011). Primary data was collected by use of questionnaires, coded and analyzed using SPSS version 20.0. The data collected from seed experts was subjected to content analysis and key summaries were made. The findings are presented in form of tables and discussions and interpretation of the same given.

\section{Results and Discussion}

\subsection{Response Rate}

The number of questionnaires administered to all the respondents, was 96 . A total of 79 questionnaires were properly filled and returned from the seed companies' staff. This represented an overall successful response rate of $82 \%$. According to O. M. Mugenda and A. G. Mugenda (2003), a response rate of $50 \%$ or more is adequate. Babbie (2004) also asserted that return response rates of $50 \%$ are acceptable to analyze and publish, $60 \%$ is good and $70 \%$ is very good. This high response rate implies that the results can be generalized to the whole population and it's a good representative of the target population.

\subsection{Reliability Analysis}

Using Cronbach's Coefficient Alpha test on product quality, a coefficient of 0.943 was found as shown in Table 1. These results corroborates findings by Saunders, Lewis, and Thornhill (2009), and Christensen, Johnson, and Turner (2011) who stated that scales of 0.7 and above, indicate satisfactory reliability. Based on these recommendations, the statements under the product quality variable of this study were concluded to have adequate internal consistency, therefore, reliable for the analysis and generalization on the population.

Table 1. Reliability test for product quality

\begin{tabular}{ll}
\hline Variable & Product Quality \\
\hline Number of items & 6 \\
Cronbach's Alpha & 0.943 \\
\hline
\end{tabular}

\subsection{Factor Analysis}

The factor loadings for sub-constructs of product quality showed that all statements had coefficients of more than 0.4 hence all the statements were retained for analysis. According to Rahn (2010), and Malakouti, Fatollahi, Mirabzadeh, Salavati, and Zandi (2006) a factor loading equal to or greater than 0.4 is considered adequate. This is further supported by Morley, Williams, and Black (2002) who asserts that a factor loading of 0.4 has good factor stability and deemed to lead to desirable and acceptable solutions.

\subsection{Descriptive Statistics}

The objective of the study was to determine the influence of product quality on organizational performance of seed maize companies in Kenya. Table 2 indicates that $88.6 \%$ of the respondents agreed that the original source of seed can affect product credibility and sales, $88.6 \%$ agreed that seed certification standards influence product credibility and sales, and $86 \%$ agreed that characteristics of seed varieties affect product performance. Eighty four point eight percent of the respondents agreed that use of trained personnel influences seed sales, $86.1 \%$ agreed that existence of physical locations for customer feedback gathering influence seed \& company credibility and 51.9\% agreed that use of hotlines to report seed failure influences the credibility of the seed and the distributor. The mean score for the responses was 3.96 which indicates that many employees agreed to the statements regarding influence of product quality on organizational performance of seed maize companies in Kenya. The study findings are consistent with those of Arawati et al. (2009) who conducted a study on the impact of quality management $(\mathrm{QM})$ practices on productivity and profitability using a sample of manufacturing companies in Malaysia. The results of Arawati et al. (2009)'s study revealed that quality measurement, benchmarking in particular as well as employee focus, supplier relations and training appear to be of primary importance and exhibit significant impact toward productivity and profitability. 
Table 2. Product quality descriptive statistics

\begin{tabular}{|c|c|c|c|c|c|c|}
\hline Statement & $\begin{array}{l}\text { Strongly } \\
\text { disagree }\end{array}$ & Disagree & Neutral & Agree & $\begin{array}{l}\text { Strongly } \\
\text { agree }\end{array}$ & $\begin{array}{l}\text { Likert } \\
\text { mean }\end{array}$ \\
\hline $\begin{array}{l}\text { The original source of seed can affect product } \\
\text { credibility and sales }\end{array}$ & $3.8 \%$ & $5.1 \%$ & $2.5 \%$ & $45.6 \%$ & $43.0 \%$ & 4.19 \\
\hline $\begin{array}{l}\text { Seed certification standards influence product } \\
\text { credibility and sales }\end{array}$ & $3.8 \%$ & $5.1 \%$ & $2.5 \%$ & $49.4 \%$ & $39.2 \%$ & 4.15 \\
\hline $\begin{array}{l}\text { Characteristics of seed varieties affect product } \\
\text { performance }\end{array}$ & $3.8 \%$ & $5.1 \%$ & $5.1 \%$ & $54.4 \%$ & $31.6 \%$ & 4.05 \\
\hline Use of trained personnel influences seed sales & $3.8 \%$ & $5.1 \%$ & $6.3 \%$ & $35.4 \%$ & $49.4 \%$ & 4.22 \\
\hline $\begin{array}{l}\text { Existence of physical locations for customer feedback } \\
\text { gathering influence seed \& company credibility }\end{array}$ & $3.8 \%$ & $5.1 \%$ & $5.1 \%$ & $82.3 \%$ & $3.8 \%$ & 3.77 \\
\hline $\begin{array}{l}\text { Use of hotlines to report seed failure influences the } \\
\text { credibility of the seed and the distributor }\end{array}$ & $5.1 \%$ & $6.3 \%$ & $36.7 \%$ & $51.9 \%$ & $0.0 \%$ & 3.35 \\
\hline Average & $4.0 \%$ & $5.3 \%$ & $9.7 \%$ & $53.2 \%$ & $27.8 \%$ & 3.96 \\
\hline
\end{tabular}

The results of this study are in support of Youngdahl and Kellogg (1997) who examined the relationship between customer service, quality assurance, satisfaction and effort, all this in the perspective of the costs of quality and found that the classification of costs to quality customer service and their relationship with both satisfaction and effort, provides important capabilities to the design and implementation of services. Thus, the cost of quality concept predicts that as quality increases the total cost of quality decreases (Hendricks \& Singhal, 2001). The internal and managerial motivation to adopt ISO 9000 often has a positive effect on the likelihood of a certified organization to achieve a better-performing effectiveness configuration (Boiral \& Amara, 2009).

The seed experts highlighted that inconsistent policies to regulate seed systems and poor seed quality control affects the supply of high quality seed to farmers by the seed industry. This is exacerbated by the supply of fake seed by unregistered players. Experts argued that the supply of poor quality and fake seed results in farmers being frustrated by poor performance of such seed and affects repeat sales. New and small seed companies are affected the most by such challenges.

The limited internal technical capacity of small seed companies on implementing quality management systems (QMS) was also reported to cause poor seed quality. The reliance on Government seed regulators was also reported to be not enough due to limited resources and personnel in the relevant Government department. The Government seed inspectors cannot cope with the increased number of seed companies, seed out-growers and seed crops. Self-regulation which allows the regulator to train and gazette selected private seed company inspectors in order to enable them to carryout seed certification effectively would result in greater compliance to seed standards ensuring high quality seed is produced. In order to discourage the supply of fake seed to farmers, the seed experts recommended highly deterrent punishments for dealing in fake seed since the current ones are too light. Fake seed dealers affect the volume of sales for certified seed and also use of such seed reduces the productivity of farmers.

\subsection{Product Quality Linearity Test}

Linearity of variables was tested using correlation coefficients as suggested by Cohen, Cohen, West and Aiken (2003). To establish whether there is a linear relationship, the study adopted the Pearson product of moment's correlation coefficients (Table 3). The results indicate that the variables organizational performance and product quality had a strong positive relationship as indicated by a correlation coefficient of 0.813 . This implies that there is a linear positive relationship.

\subsection{Regression Analysis}

A multiple regression analysis was conducted to investigate the joint causal relationship between the independent variables which are product quality and organizational performance of seed maize companies in Kenya. This is represented by the overall model:

$$
Y=\beta_{0}+\beta_{1} X_{1}+e
$$

The coefficient of determination $\mathrm{R}^{2}$ and correlation coefficient (r) show that the degree of association between product quality and organizational performance is strong (Table 3 ). An R squared of 0.662 indicates that $66.2 \%$ of the variations in organizational performance are explained by the variations in product quality. 
Table 3. Model summary

\begin{tabular}{lllll}
\hline Model & R & R Square & Adjusted R Square & Std. Error of the Estimate \\
\hline 1 & $.813^{\mathrm{a}}$ & .662 & .657 & .38489 \\
\hline
\end{tabular}

Note. a. Predictors: (Constant), Product Quality.

An F-statistic of 150.492 indicates that the overall model is significant (Table 4). The findings imply that product quality was statistically significant in explaining organizational performance of seed maize companies in Kenya. The study findings disagree with those of Terziovski et al. (1997) who conducted a study whose objective was to test the relationship between ISO 9000 certification and organizational performance in the presence and absence of a total quality management (TQM) environment. The study found out that the ISO 9000 certification does not have a significantly positive effect on organizational performance on its own. The authors say that the main motivation for companies to have a quality certification is the ability of certification to open doors to new customers that would be difficult to achieve without the quality certification.

Table 4. ANOVA for product quality

\begin{tabular}{lllllll}
\hline Model & & Sum of Squares & df & Mean Square & F & Sig. \\
\hline 1 & Regression & 22.294 & 1 & 22.294 & 150.492 & $.000^{\mathrm{b}}$ \\
& Residual & 11.407 & 77 & .148 & & \\
& Total & 33.701 & 78 & & & \\
\hline
\end{tabular}

Note. a. Dependent variable: organization performance; b. Predictors: (Constant), Product Quality.

The product quality coefficients that are presented in Table 5 show that product quality contributes significantly to the model since the p-value for the constant and gradient are less than 0.05 . The findings imply that one positive unit change in product quality effectiveness leads to a change in organizational performance at the rate of 56.4 percent. This confirms the positive effect of product quality on organizational performance. The fitted equation is as shown below:

$$
Y=1.484+0.564 X_{1}
$$

Table 5. Coefficients of product quality

\begin{tabular}{|c|c|c|c|c|c|c|}
\hline \multirow[t]{2}{*}{ Model } & & \multicolumn{2}{|c|}{ Unstandardized Coefficients } & \multirow{2}{*}{$\begin{array}{l}\text { Standardized Coefficients } \\
\text { Beta }\end{array}$} & \multirow{2}{*}{$\mathrm{t}$} & \multirow{2}{*}{ Sig. } \\
\hline & & $\mathrm{B}$ & Std. Error & & & \\
\hline \multirow[t]{2}{*}{1} & (Constant) & 1.484 & .175 & & 8.459 & .000 \\
\hline & Product Quality & .564 & .046 & .813 & 12.268 & .000 \\
\hline
\end{tabular}

Note. Dependent variable: organization performance.

\section{Conclusion and Recommendations}

Product quality had a positive significant effect on organizational performance and it was concluded that managers can increase profitability by putting in place appropriate quality management systems (QMS) and product quality standardization of seeds produced to ensure high quality seed. This therefore, can be achieved by ensuring that the original source of seeds is credible, enhancing seed certification standards to increase product credibility and sales. The study further concluded that by provision of seed varieties with different adaptable characteristics, use of trained personnel and existence of physical locations for customer feedback gathering, influenced seed and company credibility.

The study recommends that the management of seed companies should ensure they embark on improving the product quality of seeds produced so as to meet customer requirements and enhance the firm's performance and competitiveness. This can be achieved by implementing appropriate QMS, securing contracts with large farmers who have irrigation facilities to guarantee adequate seed fields isolation, high productivity and quality seed production. This would also result in high seed yields, hence reduction in the cost of production per tonne. The seed companies should also ensure strong follow-up by regulatory body for credible seed certification and giving 
advice and continuous training and creating awareness to seed out-growers. Employment and retention of experienced field staff also would result in consistently high quality seed.

\section{Acknowledgements}

The authors are grateful to the managers and staff of the seed companies for their cooperation during data collection for the study.

\section{References}

AFSTA (African Seed Trade Association). (2010). Baseline study/survey report on the Seed Sector in Kenya. Retrieved from http://afsta.org/wp-content/uploads/documents/KENYA\%20SEED\%SECTOR\%20BASELI NE\%20STUDY.pdf

AGRA (Alliance for a Green Revolution in Africa). (2013). Africa Agriculture status report: Focus on staple crops. Nairobi, Kenya. Retrieved from https://agra.org/africa-agriculture-status-report-2013/

Arawati, A., Ahmad, M. S., \& Muhammad, J. (2009). An empirical investigation on the impact of quality management on productivity and profitability: Associations and mediating effect. Contemporary Management Research, 5(1). https://doi.org/10.7903/cmr.1177

Babbie, E. (2004). The Practice of Social Research (13th ed.). Belmont: Wadsworth Thomson.

Boiral, O., \& Amara, N. (2009). Paradoxes of ISO 9000 performance: A configurational Approach. Quality Management Journal, 16(3), 37-60. https://doi.org/10.1080/10686967.2009.11918240

Casadésus, M., \& Giménez, G. (2000). The benefits of the implementation of the ISO 9000 standard: Empirical research in 288 Spanish companies. The TQM Magazine, 12(6), 432-441. https://doi.org/10.1108/0954478 0010351751

Christensen, L. B., Johnson, R. B., \& Turner, L. A. (2011). Research Methods, Design, and Analysis (11th ed.). Boston, USA. Pearson Education, Inc.

Cohen, J., Cohen, P., West, S. G., \& Aiken, L. S. (2003). Applied Multiple Regression/Correlation Analysis for the Behavioral Sciences (3rd ed.). Mahwah, New Jersey: Lawrence Erlbaum Associate Publishers.

Cooper, D. R., \& Schindler, P. S. (2011). Business Research Methods (11th ed.). McGraw-Hill Publishing Co. Ltd., New Delhi, India.

FAO (Food and Agriculture Organization). (2004). The state of food insecurity in the world 2004. Annual report by Economic and Social Department. Rome, Italy: FAO. Retrieved from http://www.fao.org/3/a-y5650e.pdf

Hendricks, K. B., \& Singhal, V. R. (2001). Firm characteristics, total quality management, and financial performance. Journal of Operations Management, 19(3), 269-285. https://doi.org/10.1016/s0272-6963(00) 00049-8

Langyintuo, A. S., Mwangi, W., Diallo, A. O., MacRobert, J., Dixon, J., \& Banziger, M. (2008). An analysis of the bottlenecks affecting the production and development of maize seed in eastern and southern Africa. Harare, Zimbabwe, CIMMYT. Retrieved from http://dtma.cimmyt.org/index.php/publications/doc_view/ 82-dtma-seed-sector-analysis-in-eastern-and-southern-africa-2008

Langyintuo, A. S., Mwangi, W., Diallo, A. O., MacRobert, J., Dixon, J., \& Banziger, M. (2009). An analysis of the challenges of the maize seed industry in eastern and southern Africa. Contributed Paper presented at the International Association of Agricultural Economists Conference, Beijing, China. Retrieved from https://ageconsearch.umn.edu/bitstream/51713/2/Seeds-paper-2009-uploaded.pdf

Langyintuo, A. S., Mwangi, W., Diallo, A. O., MacRobert, J., Dixon, J., \& Bänziger, M. (2010). Challenges of the maize seed industry in eastern and southern Africa: A compelling case for private-public intervention to promote growth. Food Policy, 35, 323-331. https://doi.org/10.1016/j.foodpol.2010.01.005

MacRobert, J. F. (2009). Seed business management in Africa. Harare, Zimbabwe, CIMMYT.

Malakouti, S. K., Fatollahi, P., Mirabzadeh, A., Salavati, M., \& Zandi, T. (2006). Reliability, validity and factor structure of the GDS-15 in Iranian elderly. International Journal of Geriatric Psychiatry, 21, 588-593. https://doi.org/10.1002/gps.1533

Morley, S., Williams, A. C., \& Black, S. (2002). A confirmatory factor analysis. Elsevier Pain., 99, $289-298$. https://doi.org/10.1016/S0304-3959(02)00137-9 
Mugenda, O. M., \& Mugenda, A. G. (2003). Quantitative and Qualitative Approaches (2nd ed.). Nairobi, Acts Press.

Pixley, K., \& Bazinger, M. (2004). Open Pollinated Maize varieties: A background step or valuable option for farmers? In D. K. Friesen, \& A. E. F. Palmer (Eds.), Integrated approaches to higher maize productivity in the new millennium. Proceedings of the Seven Eastern and Southern Africa Regional Maize Conference, $11^{\text {th }}-15^{\text {th }}$ February 2002, Nairobi, Kenya, CIMMYT (International Maize and Wheat Improvement Center) and KARI (Kenya Agricultural Research Institute).

Rahn, M. (2010). Factor analysis: A short introduction on dropping unimportant variables from your analysis. The Analysis Factor: Making Statistics Make Sense, 5.

Saunders, M., Lewis, P., \& Thornhill, A. (2009). Research Methods for Business Students (5th ed.). London, Thousand Oaks, Sage. Retrieved from https://eclass.teicrete.gr/modules/document/file.php/DLH105/ Research\%20Methods\%20for\%20Business\%20Students\%2C\%205th\%20Edition.pdf

Setimela, P. S., Badu-Apraku, B., \& Mwangi, W. (2010). Impediments to new improved maize variety testing and release in selected countries in sub-Saharan Africa. Journal of Agricultural Science and Technology, $4(6), 79-85$.

Terziovski, M., Samson, D., \& Dow, D. (1997).The business value of quality management systems certification. Evidence from Australia and New Zealand. Journal of Operations Management, 15(1), 1-18. https://doi.org/ 10.1016/S0272-6963(96)00103-9

Youngdahl, W. E., \& Kellogg, D. L. (1997). The relationship between service customers' quality assurance behaviors, satisfaction, and effort: A cost of quality perspective. Journal of Operations Management, 15(1), 19-32. https://doi.org/10.1016/S0272-6963(96)00097-6

\section{Copyrights}

Copyright for this article is retained by the author(s), with first publication rights granted to the journal.

This is an open-access article distributed under the terms and conditions of the Creative Commons Attribution license (http://creativecommons.org/licenses/by/4.0/). 